energy expenditure (cal/DMi). $\boldsymbol{r}=-0.82 \pm 0.05$ for total ingestion (DM + water). The relative value of the energy expenditure during feeding was small compared to total heat expenditure and to extra heat production.

\title{
ESSAI DE PRÉVISION DE LA VALEUR EN ÉNERgIE DIGESTIBLE DES ALIMENTS pouR LE PORC, A PARTIR DE LEURS TENEURS EN CONSTITUANTS MEMBRANAIRES
}

\author{
Y. HENRY \\ Station de Recherches sur l'Élevage des Porcs, \\ Centre national de Recherches zootechniques, I. N.R. A., \\ 78 - Jouy-en-Josas

\section{RÉSUMÉ}

$\mathrm{Au}$ cours de 4 essais de digestibilité sur un effectif total de 64 porcs mâles castrés, de race Large White, et d'un poids vif moyen de $3^{2}, 5 \mathrm{~kg}$, il a été procédé à l'étude de l'influence du taux d'incorporation d'un aliment cellulosique (farine de luzerne déshydratée, son de blé) dans des rations renfermant une céréale unique (blé, maîs ou orge).

Les résultats obtenus sur l'ensemble des régimes font apparaître une décroissance linéaire du coefficient d'utilisation digestive apparent de l'énergie (CUDE) en fonction du taux de substances cellulosiques, dosées soit par la méthode de WEENDE (cellulose brute), soit par les méthodes de VAN SoEst (résidus d'extraction au détergent en milieu acide : ADF, ou neutre NDF), suivant les relations :

$$
\begin{array}{cl}
\text { Cellulose brute } & \text { CUDE }=96,3 \mathrm{I}-2,98 x ; r=-0,929 \\
\text { ADF } & : \text { CUDE }=95,42-2,20 x ; r=-0,943 \\
\text { NDF } & : \text { CUDE }=96,36-0,872 x ; r=-0,947,
\end{array}
$$

$x$ étant le pourcentage de substances cellulosiques dans la matière sèche, et $v$ le coefficient de corrélation.

L'absence d'interaction entre les composants de la ration, tout au moins dans les limites considérées (entre 2 et 8 p. roo de cellulose brute par rapport à la matière sèche), permet d'estimer indifféremment la valeur énergétique de la ration totale et celle des aliments simples. De l'étude des variations du contenu énergétique de la matière organique fécale, il ressort en outre que les constituants membranaires totaux (cellulose + hémicelluloses + lignine) représentent le meilleur critère pour la prévision de l'utilisation digestive de l'énergie par le porc, tandis que la cellulose brute et l'ADF ne rendent compte que d'une manière imparfaite des variations observées. La valeur en énergie digestible (ED) peut être ainsi estimée simplement à partir du CUD de la matière organique (CUD MO) et du taux de constituants membranaires (NDF : entre 8 et 26 p. roo de la matière sèche) dans la ration, d'après la relation :

$$
\mathrm{ED}=\mathrm{EB}-\mathrm{MO} \times \frac{(\mathrm{IOO}-\mathrm{CUD} \mathrm{MO})}{\mathrm{I00}} \times(5,62 \mathrm{I}-0,02 \mathrm{I} 65 \mathrm{NDF})
$$

$\mathrm{Kcal} / \mathrm{kgms} \mathrm{Kcal} / \mathrm{kgms} \mathrm{g} / \mathrm{kgms} \quad$ p. Ioo MS

EB et MO étant respectivement l'énergie brute et la matière organique. 


\section{SUMMARY}

\section{PREDICTION OF THE DIGESTIBLE ENERGY VALUE OF PIG DIETS FROM THEIR FIBER CONTENT}

Four digestibility trials were conducted on $6_{4}$ castrated male Large White pigs, in order to study the influence of increasing levels of a fibrous feed (alfalfa dehydrated meal, wheat bran) in a cereal diet, based on wheat, maize or barley.

From the overall results obtained for average bodyweight of $32.5 \mathrm{~kg}$, it appears that the apparent digestibility of energy (ADE) decreases linearly according to the fiber content of the diet, whether it is determined by the WEENDE method (crude fiber) or by the VAN SoEst methods (Acid Detergent Fiber : ADF, or Neutral Detergent Fiber : NDF). The equations are the following:

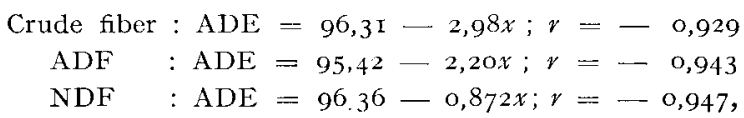

$x$ being the fiber content as a percentage of dry matter, and $r$, the correlation coefficient.

Since there is no interaction between the dietary components, at least in our experimental conditions (i-e between 2 and 8 p. 100 crude fiber in the dry matter), it is possible to predict the energy value of the entire diet as well for the single feeds.

Moreover, after studying the variation of the energy content of fecal organic matter, it follows that the total cell wall content (cellulose + hemicellulose + lignine) is a better index for predicting the digestible energy value of the diet than crude fiber or ADF. The digestible energy value (DE) may be simply estimated from the apparent digestibility of organic matter (AD OM) and the cell wall content (NDF) in the diet, through the following equation, between 8 and 26 p. 100 NDF in the dry matter (DM) :

$$
\mathrm{DE}=\mathrm{BE}-\mathrm{OM} \times \frac{(\mathrm{IO0}-\mathrm{AD} \mathrm{OM})}{\mathrm{IO0}} \times(5.62 \mathrm{I}-0,2 \mathrm{I} 65 \mathrm{NDF})
$$

$$
\text { kcal/kgDM kcal/kgDM g/kgDM }
$$

p. Ioo DM

$\mathrm{BE}$ and $\mathrm{OM}$ being respectively crude energy and organic matter. 